\title{
Pelatihan Legal Due Diligence pada Kantor Hukum Sebagai Upaya Diversifikasi Layanan Jasa Hukum
}

\author{
Budi Endarto', Arief Syahrul Alam², Dwi Elok Indriastuty ${ }^{3}$ \\ 1,2,3 Fakultas Hukum, Universitas Wijaya Putra \\ budiendarto@uwp.ac.id, sahrulalam@uwp.ac.id, dwielok@uwp.ac.id
}

\begin{abstract}
Abstrak
Jumlah Advokat di Surabaya di tahun 2020 tercatat sebanyak 1806 orang, dimana sebagian besar memberikan layanan jasa hukum yang sama yakni di bidang litigasi. Kondisi tersebut menjadikan tingkat persaingan yang sangat tinggi di antara kantor hukum karena memberikan layanan jasa hukum yang relatif sama. Sampai dengan sejauh ini baru teridentifikasi sebanyak 8 (delapan) kantor hukum yang memiliki keahlian dan pengalaman melakukan legal due diligence sebagai salah satu bentuk layanan jasa hukum yang ditawarkan. Berdasarkan hal tersebut, kami melakukan kegiatan pengabdian kepada masyarakat dalam bentuk pelatihan penyusunan dan pendampingan pelaksanaan legal due diligence pada kantor hukum Erri Meta and Partners. Tujuan program ini yang pertama adalah memberikan pelatihan penyusunan legal due diligence, kedua mengembangkan diversifikasi layanan jasa hukum. Metode yang digunakan dalam pelaksanaan program ini pertama, memberikan pelatihan penyusunan legal due diligence. Kedua, melakukan pendampingan penyusunan legal due diligence pada klien mitra. Program ini menghasilkan yang pertama pengembangan produk layanan jasa hukum berupa legal due diligence. Kedua, dihasilkan dan diterapkannya buku panduan penyusunan legal due diligence. Ketiga, adanya penambahan 2 (dua) klien baru yang memerlukan layanan jasa hukum berupa legal due diligence pada kantor hukum mitra.
\end{abstract}

Kata Kunci: Kantor Hukum, Layanan Jasa Hukum, Legal Due Diligence, Diversifikasi.

\section{PENDAHULUAN}

Advokat yang tercatat pada Dewan Pimpinan Cabang Surabaya, Perhimpunan Advokat Indonesia (Peradi) sampai dengan tahun 2020 sebanyak 1806 orang (peradidpcsurabaya.or.id). Dari sejumlah Advokat tersebut, sebagian besar memberikan layanan jasa hukum di bidang litigasi. Kondisi tersebut menjadikan tingkat persaingan yang sangat tinggi di antara kantor hukum sebagai wadah dari para Advokat karena memberikan layanan jasa hukum yang relatif sama.

Secara normatif, eksistensi profesi Advokat diatur di dalam Pasal 1 ayat 1, Undangundang No. 18 Tahun 2003 tentang
Advokat, yang menyebutkan bahwa “...Advokat adalah orang yang berprofesi memberikan jasa hukum, baik di dalam maupun diluar pengadilan yang memenuhi persyaratan berdasarkan ketentuan Undang-undang ini". Hal tersebut lebih ditegaskan dalam Pasal 1 angka 2 UU Advokat, dimana yang dimaksud dengan jasa hukum adalah: “... jasa yang diberikan Advokat berupa memberikan konsultasi hukum, bantuan hukum, menjalankan kuasa, mewakili, mendampingi, membela dan melakukan tindakan hukum lain untuk kepentingan hukum klien. Dari kedua rumusan tersebut, tidaklah salah apabila sebagian besar kantor hukum sebagai wadah kegiatan 
advokat di Surabaya, orientasi jasa hukum yang diberikan hanya sebatas pada memberikan bantuan hukum, menjalankan kuasa, mewakili, mendampingi, membela dan melakukan tindakan hukum di pengadilan atau yang lazim disebut layanan jasa hukum litigasi.

Apabila dicermati lagi ketentuan Pasal 1 ayat 1 dan ayat 2 UU Advokat, seorang Advokat juga dapat berfungsi sebagai konsultan hukum. Berdasarkan fungsinya seorang Advokat sebagai konsultan hukum dapat memberikan jasa hukum berbentuk pemeriksaan dan memberikan pendapat hukum yang berlandaskan hukum dan praktek terbaik (best practices) (Indra Safitri, 2013). Jasa hukum berupa pemeriksaan dan pemberian pendapat hukum dikenal dengan legal due diligence.

Legal due diligence, berasal dari kata dasar diligence yang dibagi menjadi dua tipe utama yaitu: diligentia quam suis rebus atau the care that and ordinary person exercise in managing his or her own affairs, dan diligentia exactissima or diligentia boni patrisfamilia, atau a more exacting type of care exercised by the head of a family (Alexandra Reed Lajoux, 2010). Black's Law Dictionary mendefinisikan due diligence sebagai "...the diligence reasonably expected from, and ordinarily exercised by, a person who seeks to satisfy a legal requirement or to discharge an obligation"(Bryan A. Garner, 2019).

Dalam perspektif praktis, Alexandra Reed Lajoux berpendapat bahwa aktifitas legal due diligence dapat diartikan sebagai review terhadap kepatuhan korporasi baik terhadap financial statement, operasional maupun terhadap aturan-aturan hukum yang berlaku sebagaimana pernyataannya"...Due Diligence Process, including a review of financial statement, operational and management, and legal compliance..." (Alexandra Reed Lajoux, 2010). Selanjutnya Gordon Bing menjelaskan bahwa due diligence merupakan the first step in planning a due diligence program is to define its objectives (Gordon, Bing, 2016). Dalam melakukan due diligence dari aspek hukum menurut Alexandra Reed adalah untuk meminimalisir potensi permasalahan hukum sebagaimana di uraikan "...legal compliance review, responsible due diligence process that uncovers current and potential causes of financial, operational and legal problems. This process itself can eliminate about of potential suits againt directors and officers (Alexandra Reed Lajoux, 2010).

Sampai dengan sejauh ini pengertian legal due diligence tidak ditemukan padanannya di Indonesia. Pengertian legal due diligence ditemukan dalam standar profesi Himpunan Konsultan Hukum Pasar Modal dengan menggunakan terminologi uji tuntas dari segi hukum, yang memiliki pengertian "kegiatan pemeriksaan secara seksama dari segi hukum oleh Konsultan Hukum terhadap suatu perusahaan atau obyek transaksi sesuai dengan tujuan transaksinya, untuk memperoleh informasi atau fakta material yang dapat menggambarkan kondisi suatu perusahaan atau obyek transaksi" (Himpunan Konsultan Hukum Pasar, 2018).

Dari beberapa pengertian tersebut, legal due diligence dapat dijelaskan sebagai bentuk layanan jasa hukum yang dapat diberikan oleh Advokat di luar fungsinya di bidang litigasi yakni untuk melakukan pemeriksaan dan pemberian pendapat hukum terhadap suatu perusahaan yang akan melakukan transaksi-transaksi dalam menjalankan kegiatan usahanya. Transaksitransaksi yang dimaksudkan disini adalah sebagai salah satu bentuk corporate action yang dilakukan oleh suatu perusahaan. Sedangkan yang dimaksud sebagai corporate action itu sendiri adalah suatu aksi perusahan yang dapat mengakibatkan atau berdampak pada perubahan struktur pada perusahaan tersebut. Hal ini sejalan dengan pengertian corporate action 
sebagaimana disampaikan oleh Francis Groven yang menyatakan" ...corporate action occurs when changes are made to the capital structure or financial position of an issuer of a security that affect any of the securities it has issue (Francis Groves, 2018). Adapun bentuk-bentuk corporate action yang lazim dilakukan seperti pengambilalihan usaha, penggabungan usaha, dan peleburan usaha (Mas Rahmah, 2019).

Dalam pelaksanaan kegiatan pengabdian kepada masyarakat ini, kantor hukum yang dipilih menjadi mitra adalah Erri Meta and Partners dan Erri Meta, S.H., M.H., sebagai Managing Partners. Berdasarkan hasil wawancara awal yang dilakukan, seluruh advokat yang tergabung dalam kantor hukum tersebut tidak memahami serta tidak memiliki pengalaman melakukan legal due diligence. Hal ini disebabkan karena selama ini jasa hukum yang diberikan oleh kantor hukum tersebut di bidang litigasi.

Permasalahan yang mitra hadapi adalah belum memiliki pengalaman memberikan jasa hukum berupa legal due diligence dan oleh karenanya tidak memahami model dan metode layanan jasa hukum dalam bentuk legal due diligence. Oleh karena itu maka dari pelaksanaan kegiatan pengabdian ini diharapkan dapat memberikan ketrampilan hukum melakukan legal due diligence serta mewujudkan diversifikasi layanan jasa hukum mitra yang pada akhirnya dapat meningkatkan pendapatan mitra.

Berangkat dari permasalahan tersebut, pelaksanaan program ini yang pertama adalah memberikan pelatihan legal due diligence untuk pengembangan atau diversifikasi layanan jasa hukum terhadap mitra. Yang kedua adalah memberikan pendampingan pada pelaksanaan pekerjaan legal due diligence pada klien mitra.

\section{METODE}

Pelaksanaan kegiatan pengabdian kepada masyarakat ini dimulai pada bulan Februari 2020 sampai dengan bulan Agustus 2020. Akan tetapi kegiatan ini tetap dilanjutkan untuk melakukan evaluasi terhadap hasil pelatihan dan pendampingan pelaksanaan pekerjaan legal due diligence yang dilakukan oleh mitra sampai dengan bulan Desember 2020.

Metode yang digunakan dalam melaksanakan kegiatan pengabdian kepada masyarakat ini adalah pelatihan penyusunan legal due diligence yang diberikan kepada para seluruh lawyer yang tergabung dalam kantor hukum Erri Meta and Partners. Selanjutnya sebagai tindak lanjut dari pelatihan juga dilakukan evaluasi terhadap penerapan materi pelatihan legal due diligence.

Selain diberikan pelatihan, juga dilakukan pendampingan pada pertemuan dengan klien mitra maupun pendampingan dalam rangka pelaksanaan pekerjaan legal due diligence. Pendampingan terhadap pelaksanaan pekerjaan legal due diligence terhadap klien mitra ini sangat diperlukan dengan pertimbangan bahwa disamping sebagai sarana evaluasi terhadap hasil pelatihan juga untuk memastikan kualitas hasil pekerjaan yang dilaksanakan oleh mitra.

\section{HASIL DAN PEMBAHASAN \\ Pelatihan Penyusunan Legal Due Diligence}

Pelaksanaan kegiatan pelatihan legal due diligence dilaksanakan dalam 4 (empat) kali pertemuan yakni tanggal 22 dan 29 Februari 2020 serta dilanjutkan pada tanggal 7 dan 14 Maret 2020. Pelatihan dilaksanakan di Kantor Hukum Erri Meta and Partners yang beralamat di Jl. Ngagel Tama No. 85, Surabaya. Dalam pelatihan tersebut diikuti oleh seluruh Advokat sebanyak 7 (tujuh) orang yang seluruhnya memiliki izin praktek sebagai Advokat. Keikutsertaan seluruh Advokat yang tergabung dalam Erri Meta and Partners,

Sub Tema Ekonomi, Sosial dan Budaya 978 
diharapkan agar Advokat yang tergabung dalam kantor hukum tersebut selain mendapatkan pengetahuan tentang legal due diligence, juga memahami perencanaan kantor hukum mitra yang akan melakukan diversifikasi produk layanan jasa hukumnya.

Terkait dengan diversifikasi, terdapat beberapa pandangan diantaranya Philip Kotler dan Gary Amstrong yang mendefinisikan diversifikasi produk sebagai salah satu cara untuk meningkatkan bisnis yang ada dengan jalan mengidentifikasi peluang untuk menambah bisnis perusahaan saat ini (Philip Kotler dan Gary Amstrong, 2001). Sedangkan Fandy Tjiptono berpendapat bahwa diversifikasi adalah upaya mencari dan mengembangkan produk atau pasar yang baru atau keduanya dalam rangka mengejar pertumbuhan, peningkatan penjualan, profitabilitas dan fleksibilitas (Fandy Tjiptono,2008). Pandangan yang berbeda disampaikan oleh Siti Aisjah, yang melihat diversifikasi dari sisi strategi sebagimana dijelaskannya bahwa secara teoritis diversifikasi perusahaan dapat dilakukan ketika mereka memiliki sumber daya, kapabilitas dan kompetensi inti yang memiliki kegunaan majemuk (Siti Aisjah,2012). Secara umum, beberapa dasar pertimbangan dalam mengadakan diversifikasi produk suatu perusahaan yaitu : (1) agar perusahaan tidak tergantung pada satu pasar saja, sehingga kekhawatiran perusahan tentang kejenuhan yang akan terjadi atas product line yang ada, (1) adanya kesempatan menghasilkan produk baru dapat mendatangkan hasil keuntungan yang lebih baik; (3) adanya unsur sinergi, dimana penambahan produk yang lain akan menimbulkan besarnya biaya tetap per unit akan menurun atau lebih rendah; (4) adanya kegiatan dalam pengembangan produk yang dapat menghasilkan atau menemukan produk baru (Khamidi, Fauzi, \& Suyadi, 2011).
Dari beberapa pandangan tersebut, pada pelaksanaan pengabdian kepada masyarakat ini merupakan upaya untuk merencanakan dan merealisasi diversifikasi produk layanan jasa hukum oleh mitra agar tidak tergantung pada satu layanan jasa hukum yakni di bidang litigasi. Proses pengembangan dan penguatan diversifikasi layanan jasa hukum dilakukan melalui kegiatan pelatihan dan pendampingan terhadap pelaksanaan legal due diligence yang dilaksanakan oleh mitra.

Pelatihan penyusunan legal due diligence dilaksanakan dengan menggunakan (2) dua orang narasumber yakni Budi Endarto dan Arief Syahrul Alam. Untuk mempersiapkan pelatihan tersebut telah disusun Buku Panduan Layanan Jasa Hukum dan Buku Panduan Legal Due Diligence (Gambar 2). Penyusunan kedua buku panduan tersebut diharapkan dapat mempermudah proses pelatihan dan mempermudah pemahaman peserta pelatihan. Pada pertemuan pertama, Budi Endarto menyampaikan materi tentang transaksi-transaksi yang memerlukan legal due diligence dan tahapan-tahapan yang wajib dilakukan dalam legal due diligence. Tahapan-tahapan yang harus dilalui adalah tahap pra perjanjian dengan klien, tahap perjanjian dan perencanaan kerja jasa hukum, tahap pemeriksaan terhadap posisi hukum dan tahap pendapat hukum (HKHPM,2018). Pada sesi berikutnya diberikan materi tentang metode pemeriksaan yang harus dilakukan oleh seorang konsultan hukum, dimana seorang konsultan hukum selain melaksanakan pemeriksaan dokumen juga harus melakukan pemeriksaan di lapangan. Hal tersebut untuk memastikan kebenaran material yang artinya apakah terdapat kesesuaian antara dokumen yang diberikan klien dengan realita di lapangan.

Dalam pelatihan tersebut diberikan materi tentang pelaksanaan legal due diligence untuk kepentingan pengambilalihan dan penggabungan usaha suatu perusahaan. 
Adapun dokumen-dokumen yang harus diperiksa untuk kepentingan pengambilalihan dan penggabungan usaha suatu perusahaan, meliputi: anggaran dasar perusahaan beserta perubahannya, notulennotulen rapat, saham dan permodalan perusahaan serta kedudukan dan keabsahan terhadap pengangkatan Komisaris dan Direksi. Pelatihan dilanjutkan dengan materi pemeriksaan terhadap perizinan dan persetujuan yang dimiliki oleh perusahaan, laporan keuangan yang telah diaudit oleh auditor independen. Dalam pemeriksaan terhadap laporan keuangan, konsultan hukum memiliki kewajiban untuk memperhatikan arus kas dan/atau atau neraca rugi-laba, utang jangka pendek dan jangka panjang, kepemilikan aset yang meliputi benda tetap, benda bergerak, dan/atau kekayaan intelektual. Setelah melakukan pemeriksaan terhadap laporan keuangan, konsultan hukum juga melakukan pemeriksaan terhadap aset meliputi status kepemilikan atau penguasaan atas asset, jangka waktu keberlakuan aset, perpajakan terkait aset, hak dan kewajiban terkait asset, perkara hukum atas aset yang dimiliki atau dikuasai perusahaan dan pembebanan atas aset yang dimiliki atau dikuasai oleh perusahaan. Dalam melakukan pemeriksaan asset, konsultan hukum wajib memeriksa kesesuaian antara dokumen dengan realitas di lapangan.

Pelatihan pada pertemuan ke 2 dilaksanakan pada tanggal 29 Ferbuari 2020, dengan materi pemeriksaan terhadap perkara hukum dan perjanjian antara perusahaan dengan dengan pihak ketiga. Pemeriksaan terhadap perkara hukum meliputi perkara hukum dibidang perdata, dibidang pidana, dibidang perpajakan, dibidang perniagaan, dibidang persaingan usaha, dibidang hubungan industrial, di bidang tata usaha negara dan perkara hukum yang penyelesaiannya melalui mediasi atau arbitrase. Dalam memeriksa perkara hukum, konsultan hukum wajib mengkaji dampak perkara tersebut terhadap tujuan legal due diligence. Berikutnya materi pelatihan pemeriksaan terhadap perjanjian dengan pihak ketiga yang meliputi pihak dalam perjanjian, objek perjanjian, nilai perjanjian, hak dan kewajiban para pihak, pembatasanpembatasan bagi para pihak sesuai dengan transaksi yang akan dilakukan, klausul pengakhiran, keadaan cidera janji, dampak perjanjian terhadap perusahan.

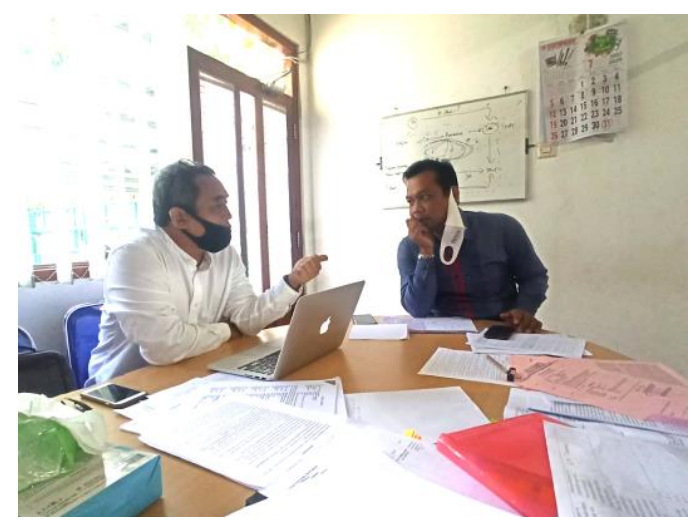

Gambar 1. Pelatihan Penyusunan Legal due Diligence

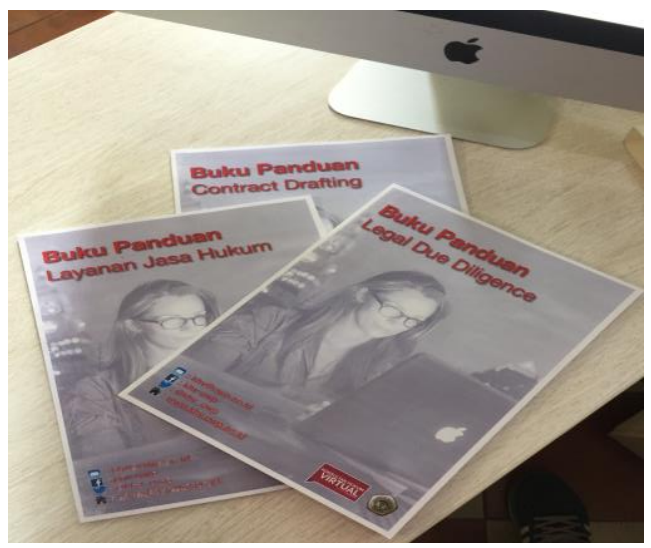

Gambar 2. Buku Panduan Legal Due Diligence

Pada pertemuan ke 3 yang dilaksanakan pada tanggal 7 Maret 2020, sebagai pemateri adalah Bapak Arief Sahrul Alam yang memberikan materi terkait dengan perpajakan perusahaan dan ketenagakerjaan. Pemeriksaan terhadap kewajiban pajak perusahaan merupakan

Sub Tema Ekonomi, Sosial dan Budaya 980 
pemeriksaan terkait kepatuhan pajak dengan memperhatikan laporan keuangan yang telah diaudit oleh auditor independen. Pemeriksaan perpajakan dilakukan dengan memperhatikan kewajiban pajak oleh perusahaan, utang pajak perusahaan, perkara perpajakan dan/atau penyelesaian tanggung jawab pajak oleh perusahaan. Selanjutnya materi tentang ketenagakerjaan, yakni pemeriksaaan yang meliputi bukti pelaporan tenaga kerja perusahaan, Kesepakatan Kerja Bersama (KKB), peraturan perusahaan, penggunaan tenaga kerja asing, jaminan sosial tenaga kerja, pemenuhan ketentuan Upah Minimum Regional (UMR) dan izin-izin khusus di bidang ketenagakerjaan. Pemeriksaan terhadap jaminan sosial tenaga kerja meliputi asuransi tenaga kerja atau BPJS Tenaga Kerja, asuransi kesehatan atau BPJS Kesehatan, asuransi jaminan hari tua dan/atau asuransi tambahan lainnya.

Pada pertemuan ke 4 dilaksanakan pada tanggal 14 Maret 2020, materi yang diberikan adalah penyusunan laporan atas pemeriksaan hukum yang dibuat oleh konsultan hukum. Konsultan hukum wajib membuat laporan atas pemeriksaan posisi hukum yang harus disusun sekurangkurangnya terdiri atas tujuan legal due diligence, keterangan terkait transaksi, batas waktu pelaksanaan legal due diligence, dan ringkasan eksekutif. Dalam pertemuan ini juga di berikan materi tentang pemberian pendapat hukum yang berbasis pada laporan pemeriksaan hukum yang telah dilakukan oleh kansultan hukum. Dalam memberikan pendapat hukum, konsultan hukum wajib didasarkan pada peraturan perundang-undangan yang berlaku. Pendapat hukum tersebut dibuat berdasarkan hasil pemeriksaan hukum yang telah dilaksanakan oleh konsultan hukum.

\section{Pendampingan Pelaksanaan Pekerjaan} Legal Due Diligence
Setelah melaksanakan program pelatihan, tahap berikutnya adalah tahap pendampingan pada aktifitas legal due diligence yang dikerjakan oleh mitra. Secara umum, konsep pendampingan berangkat dari konsep pendampingan sosial yang meliputi perencanaan, pengkoordinasian dan pengembangan berbagai aktifitas pembuatan program atau proyek kemasyarakatan (Edi Suharto, 2002). Sejalan dengan konsep pendampingan tersebut, kegiatan pengabdian kepada masyarakat ini juga memberikan pendampingan terhadap komunitas profesi Advokat yang tergabung pada satu kantor hukum. Pendampingan yang dilakukan dimulai dari tahap perencanaan, koordinasi dan pengembangan serta penyusunan program terhadap komunitas profesi tersebut.

Pada dasarnya pendampingan sosial memiliki prinsip utama sebagai "making the best of the client's resources" (Payne,1986). Pendampingan sosial berpusat pada 4 (empat) visi praktek pekerjaan sosial yaitu pemungkin (enabling), penguatan (empowering), pendukung (supporting) dan pelindung (protecting) (Edi Suharto, 2002). Berangkat dari prinsip tersebut, kegiatan pengabdian kepada masyarakat ini diharapkan dapat mewujudkan komunitas profesi tersebut berkembang berdasarkan kemampuan dan potensi yang dimiliki. Untuk itulah diperlukan dorongan dan penguatan serta dukungan dari pihak pelaksana pengabdian kepada masyarakat agar potensi yang ada pada komunitas profesi ini dapat berkembang secara maksimal.

Bentuk pendampingan yang dilakukan adalah melakukan asistensi saat kantor hukum mitra melaksanakan legal due diligence. Advokat dari kantor hukum mitra dalam melakukan legal due diligence kepada kliennya harus memperhatikan tahapan-tahapan dalam pelaksanaannya. Tahapan-tahapan yang harus dilalui adalah

Sub Tema Ekonomi, Sosial dan Budaya 981 
tahap pra perjanjian dengan klien, tahap perjanjian dan perencanaan kerja jasa hukum, tahap pemeriksaan terhadap posisi hukum dan tahap pendapat hukum (HKHPM, 2018). Hal ini sebagai bentuk proses kerja yang harus diterapkan serta sebagai bentuk komitmen bersama antara kantor hukum dengan mitra pengguna jasa akan tahapan dan schedule berdasarkan perencanaan kerja yang disepakati.

Pendampingan juga dilakukan terhadap penyusunan materi pemeriksaan yang dilakukan oleh kantor hukum mitra serta tahapan penyusunan pendapat hukum terkait dengan kegiatan transaksi pengambilalihan usaha oleh klien mitra. Pendampingan dalam pelaksaaan transaksi tersebut diberikan kepada Advokat yang ditugaskan oleh kantor hukum mitra dalam penanganan legal due diligence termasuk memberikan pendampingan pertemuanpertemuan dengan klien mitra.

Sampai dengan akhir bulan Agustus 2020, kantor hukum mitra telah memberikan 2 (dua) bentuk layanan jasa hukum berupa legal due diligence terhadap transaksi pengambialihan usaha yang dilakukan oleh kliennya. Kegiatan tersebut memberikan pengalaman pada kantor hukum mitra untuk menangangani layanan jasa hukum non litigasi. Dengan demikian maka perencanaan untuk melakukan diversifikasi layanan jasa hukum telah dapat direalisiasi pada tahun pertama sejak pelatihan dan pendampingan diberikan.

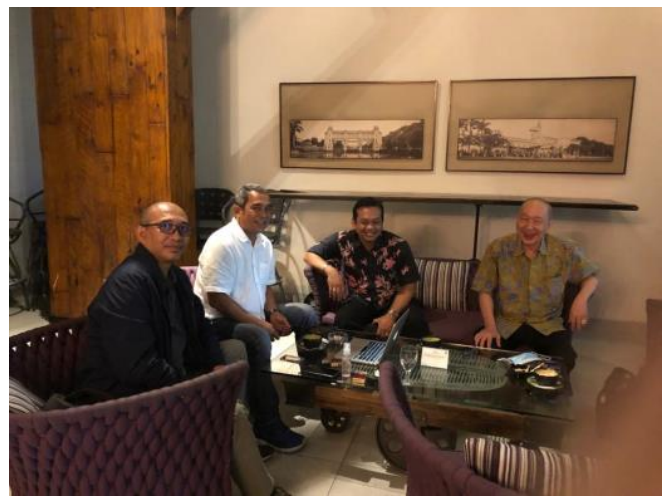

Gambar 3. Pendampingan Pelaksanaan

Legal Due Diligence Dengan Klien Mitra

\section{SIMPULAN DAN SARAN}

Melalui program pengabdian kepada masyarakat ini dapat ditarik kesimpulan bahwa kantor hukum mitra telah memahami dan memiliki ketrampilan dalam memberikan layanan jasa hukum di bidang non litigasi dalam hal ini adalah legal due diligence. Dengan diperolehnya kemampuan dan ketrampilan serta pengalaman melakukan legal due diligence, maka kantor hukum mitra dapat dikatakan telah berhasil mewujudkan diversifikasi layanan jasa hukum di bidang layanan hukum non litigasi.

Manfaat yang diperoleh kantor hukum mitra terkait dengan kegiatan pelatihan dan pendampingan layanan jasa hukum legal due diligence akan meningkatkan image kantor hukum tersebut. Image yang terbangun kedepan diharapkan masyarakat pengguna jasa hukum kantor hukum mitra mengetahui dan memberikan kepercayaan pada kantor hukum mitra dalam kegiatan jasa hukum legal due diligence pada setiap corporate action yang dilakukannya.

\section{UCAPAN TERIMA KASIH}

Ucapan terima kasih disampaikan kepada Lembaga Penelitian dan Pengabdian Kepada Masyarakat, Universitas Wijaya Putra yang telah memberikan kepercayaan dan dukungan sehingga kegiatan pengabdian kepada masyarakat ini dapat terlaksana dengan baik dan lancar.

Sub Tema Ekonomi, Sosial dan Budaya 982 


\section{DAFTAR REFERENSI}

Aisjah, Siti, 2012, Strategi Diversifikasi Korporat: Penciptaan Nilai Perusahaan, UB Press, Malang.

Bing, Gordon, 2016, Due Diligence, Techniques and Analysis, Critical Questions for Business Decisions, Quorum Books, Wesport, Connecticut, London.

Garner, Bryan A., 2019, Black Law Dictionary, $11^{\text {th }}$ Edition, Thomson Reiters.

Groves, Francis, 2018, Corporate Actionsa Concise Guide:an Introduction to Securities Events, Harriman House Ltd, Great Britian.

Himpunan Konsultan Hukum Pasar Modal, Standar Profesi Konsultan Hukum Pasar Modal, 2018.

Khamidi, S., Fauzi, A., \& Suyadi, I., 2010, Pengaruh Diversifikasi Produk Terhadap Penjualan (Studi Kasus pada Perusahaan Konveksi "Faiza Bordir" Bangil-Pasuruan), Jurnal Universitas Brawijaya Malang, Malang.

Kotler, Philip dan Gary Amstrong, 2001, Prinsip-prinsip Pemasaran Edisi A, Erlangga, Jakarta.

Lajoux, Alexandra Reed, 2010, The Art Of M\& A Due Diligence, Navigating Critical Steps and Uncovering Crucial Data, Mc Graw Hill, New York.

Payne, Macolm, 1986, Social Care in The Community, MacMillian, London.

Rahmah, Mas, 2019, Hukum Pasar Modal, Kencana, Jakarta.

Safitri, Indra, Juli-November 2013, Profesi Konsultan Hukum Pasar Modal Dalam Era Otoritas Jasa Keuangan (OJK), Jurnal Hukum \& Pasar Modal, Himpunan Konsultan Hukum Pasar Modal, Volume V/Edisi 6.

Suharto, Edi, 2002, Pendampingan Sosial Dalam Pengembangan Masyarakat, Makalah disajikan pada Pelatihan
Pengembangan Masyarakat Bagi Pengurus Forum Komunikasi Pekerja Masyarakat (PSM) Tingkat Propinsi se Indonesia, Pusdiklat Tenaga Kesejahteraan Masyarakat, Depsos RI, 28 Agustus 2002.

Tjiptono, Fandy, 2008, Stategi Pemasaran, Edisi 3, Andi, Yogyakarta. 